\title{
Momordica charantia Extract Induces Apoptosis in Human Cancer Cells through Caspase- and Mitochondria-Dependent Pathways
}

\author{
Chia-Jung Li, ${ }^{1}$ Shih-Fang Tsang, ${ }^{2}$ Chun-Hao Tsai, ${ }^{3}$ Hsin-Yi Tsai, ${ }^{3}$ \\ Jong-Ho Chyuan, ${ }^{4}$ and Hsue-Yin $\mathrm{Hsu}^{1,3}$ \\ ${ }^{1}$ Institute of Medical Sciences, Tzu Chi University, Hualien 970, Taiwan \\ ${ }^{2}$ Department of Anatomy, Tzu Chi University, Hualien 970, Taiwan \\ ${ }^{3}$ Department of Life Sciences, Tzu Chi University, Hualien 970, Taiwan \\ ${ }^{4}$ Section of Crop Improvement, Hualien District Agricultural Research and Extension Station, Council of Agriculture, \\ Executive Yuan, Hualien 973, Taiwan \\ Correspondence should be addressed to Hsue-Yin Hsu, hsueyin@mail.tcu.edu.tw
}

Received 14 May 2012; Revised 24 August 2012; Accepted 5 September 2012

Academic Editor: Chun-Su Yuan

Copyright ( $) 2012$ Chia-Jung Li et al. This is an open access article distributed under the Creative Commons Attribution License, which permits unrestricted use, distribution, and reproduction in any medium, provided the original work is properly cited.

Plants are an invaluable source of potential new anti-cancer drugs. Momordica charantia is one of these plants with both edible and medical value and reported to exhibit anticancer activity. To explore the potential effectiveness of Momordica charantia, methanol extract of Momordica charantia (MCME) was used to evaluate the cytotoxic activity on four human cancer cell lines, Hone-1 nasopharyngeal carcinoma cells, AGS gastric adenocarcinoma cells, HCT-116 colorectal carcinoma cells, and CL1-0 lung adenocarcinoma cells, in this study. MCME showed cytotoxic activity towards all cancer cells tested, with the approximate $\mathrm{IC}_{50}$ ranging from 0.25 to $0.35 \mathrm{mg} / \mathrm{mL}$ at $24 \mathrm{~h}$. MCME induced cell death was found to be time-dependent in these cells. Apoptosis was demonstrated by DAPI staining and DNA fragmentation analysis using agarose gel electrophoresis. MCME activated caspase-3 and enhanced the cleavage of downstream DFF45 and PARP, subsequently leading to DNA fragmentation and nuclear condensation. The apoptogenic protein, Bax, was increased, whereas Bcl-2 was decreased after treating for $24 \mathrm{~h}$ in all cancer cells, indicating the involvement of mitochondrial pathway in MCME-induced cell death. These findings indicate that MCME has cytotoxic effects on human cancer cells and exhibits promising anti-cancer activity by triggering apoptosis through the regulation of caspases and mitochondria.

\section{Introduction}

Cancer is one of the leading causes of death worldwide, accounting for millions of death each year. Previous studies have examined the association between the intake of antioxidant-rich foods and beneficial effects related to the prevention of cancer, cardiovascular diseases, diabetes, and other oxidative-stress-related chronic diseases $[1,2]$. The highly reactive and bioactive phytochemical antioxidants in plants are postulated to be responsible, in part, for the protective effects of plant foods. Biochemically active phytochemicals found in plant-based foods also have many powerful biological properties that are not necessarily related to their antioxidant properties $[3,4]$. Some cancer patients use agents derived from different plants or nutrients as complementary or alternative medicines, exclusively or concurrently with traditional chemotherapy and/or radiotherapy [5]. Although there are increasing numbers of drugs available for patients with cancer, the effects of many drug treatments are temporary and noncurative. Due to the need for new therapeutic options for cancer therapy, the discovery of food plants with medicinal effects has prompted studies evaluating possible anticancer agents in fruits, vegetables, herbs, and spices [6].

Momordica charantia L. (bitter gourd), a member of the family Cucurbitaceae, is widely grown in tropical areas and 
used as a traditional medicine plant indigenous to China. In addition to culinary usage, $M$. charantia is also used in folklore medicine worldwide $[6,7]$. M. charantia was found to possess antiviral, antibacterial, and immunomodulatory properties and used as a topical remedy for expelling intestinal gas and treating skin problems such as scabies, eczema, and itchy rashes [8-10]. Most often, crude extracts of the bitter gourd fruits were used as hypoglycemic or antidiabetic agents in pathophysiological conditions [11]. In Taiwan, both cultivars and wild-grown $M$. charantia are found. Wild populations with smaller fruit sizes, used as a folklore medicine for a long history by aboriginal people, are native to Taiwan and currently exhibit a sympatric distribution or introgression of cultivars for agricultural purposes [12]. M. charantia contains an array of components that possess different biological activities. Extract of the fruit of $M$. charantia was suggested to modulate signal transduction pathways for inhibition of breast cancer cell growth [13]. Data from in vitro studies suggest that alpha- and beta-mormorcharin exert possible anti-herpesvirus effects [14], while momordin, a protein found in $M$. charantia, has anticancer activity in animal experiment [15]. More recently, MAP30, a 30-kDa protein isolated from seeds of $M$. charantia, has shown promising effects for treating tumors and HIV infection [16, 17]. In addition, cytotoxicity of RNases, ribosome inactivating protein, and triterpenoids isolated from the fruit of $M$. charantia on tumor cells has been demonstrated by numerous in vitro and in vivo studies [18-20].

Our preliminary assays indicated that extracts of $M$. charantia leaves obtained from eastern area of Taiwan were effective on inhibiting the growth of cancer cells. Hence the bioactivity of $M$. charantia is determined by extraction process and cultivars. To elucidate the antitumor activity of $M$. charantia with introgressed characteristics between cultivars and wild populations in the eastern Taiwan, we comparatively examined the effect of $M$. charantia methanol extract (MCME) by different human cancer cell lines in this study.

\section{Materials and Methods}

2.1. Preparation of $M$. charantia Methanol Extracts. M. charantia cultivated in the Hualien agriculture research and extension station (HARES, Hualien, Taiwan) with introgressed characteristics between cultivars and wild populations was authenticated before being used for this study. The plant material collected was identified by HARES, where a voucher specimen (no. 2381) has been deposited. The airdried leaves of $M$. charantia were soaked in methanol at room temperature for 2 months, filtered and centrifuged at $500 \times \mathrm{g}$ for $10 \mathrm{~min}$. The supernatant was evaporated under reduced pressure to afford a dark brown residue, which was lyophilized at $-80^{\circ} \mathrm{C}$. The dried extract of $M$. charantia was stored at $-20^{\circ} \mathrm{C}$ until required for treatments and dissolved in dimethyl sulfoxide with a stock concentration of $200 \mathrm{mg} / \mathrm{mL}$ before dilution with media.
2.2. Chemicals, Drugs, and Antibodies. Bovine serum albumin, 3-(4,5-dimethylthiazol-z-yl)-2,5-di-phenyl tetrazolium bromide (MTT), agarose, dimethylsulfoxide (DMSO), DMEM medium, penicillin, streptomycin, L-glutamine, sodium bicarbonate, trypsin/EDTA, propidium iodide (PI), DAPI, RNase A, Triton X-100, HEPES, $\mathrm{NaOH}, \mathrm{NaCl}$, EDTA, NP-40, Tris, sucrose, SDS, sodium deoxycholate, glycerol, Tween-20 were purchased from Sigma Chemical Company Inc. (St Louis, MO, USA). Anti-ICAD (113416), anti-caspase 3 (123678), anti-PARP (100573), anti-Bax (109683), antiBcl-2 (100064), and anti- $\beta$-actin (100315) were purchased from GeneTex Inc. (ICON-GeneTex, Hsinchu, Taiwan).

2.3. Cell Culture. To evaluate the antitumor properties of $M$. charantia, four human cancer cell lines, human nasopharyngeal carcinoma cells (Hone-1), gastric adenocarcinoma cells (AGS), colonrectal carcinoma cells (HCT-116), and lung adenocarcinoma cell (CL1-0), were used in this study. Cells were grown in DMEM, F-12 K, Mccoy's 5a and RPMI for Hone-1, AGS, HCT-116, and CL1-0 cells, respectively. All cultured media were supplemented with $10 \%$ FBS, $100 \mathrm{U} / \mathrm{mL}$ penicillin- $100 \mu \mathrm{g} / \mathrm{mL}$ streptomycin, and $0.1 \mathrm{M}$ sodium bicarbonate. Cells were maintained in a humidified incubator at $37^{\circ} \mathrm{C}$ under $5 \% \mathrm{CO}_{2}$.

2.4. Cell Viability Assay. Cytotoxicity of MCME on human cancer cells was assessed by MTT which measures the metabolic activity of viable cells as described [21]. Briefly, cells were plated out at a density of $5 \times 10^{3}$ cells/well in 96-well microtiter plates. Following overnight cell adherence, fresh medium along with the corresponding concentrations of MCME were added to the culture. Cultural media were replaced by drug-free medium and MTT solution at a final concentration of $0.5 \mathrm{mg} / \mathrm{mL}$ after treatments, and incubation was prolonged for $4 \mathrm{~h}$ at $37^{\circ} \mathrm{C}$. After carefully removing the supernatants, the MTT-formazan crystals formed by metabolically viable cells were dissolved in DMSO and absorbance was determined at $570 \mathrm{~nm}$ in a multiwell plate ELISA reader (Bio-tek Instruments, Winooski, VT, USA). The MCME concentration that caused approximate 25\% and $50 \%$ growth inhibition was calculated, respectively, from extrapolating in the trend line by using the optical density OD value of control and the treated cells.

2.5. Propidium Iodide Staining of DNA Content. All cancer cells were seeded with an appropriate density in petri dishes and allowed to grow for 24 to $48 \mathrm{~h}$ at $37^{\circ} \mathrm{C}$, in a condition of $5 \% \mathrm{CO}_{2} / 95 \%$ air. Cells were harvested after treatments and fixed overnight with $70 \%$ ethanol at $-20^{\circ} \mathrm{C}$. Cells containing apoptotic bodies were counted under fluorescence microscopic observation (IX71, Olympus Co.).

For cell cycle analysis, cells were washed twice with PBS, and resuspended in $100 \mu \mathrm{L}$ of PI solution for $30 \mathrm{~min}$ at room temperature in the dark. Distribution of cells with different DNA contents was analyzed by a FACSCalibur flow cytometer and CellQuest software (BD Biosciences, San Jose, CA, USA) at an excitation wavelength of $530 \mathrm{~nm}$. 
Fluorescence emission was measured using a $620 \mathrm{~nm}$ band pass filter.

2.6. DNA Fragmentation Assay. DNA fragments from cancer cells treated with MCME for 6, 12, 18, and $24 \mathrm{~h}$ were analyzed by agarose gel electrophoresis. Apoptotic DNA was isolated using DNA lysis buffer through the processes described previously [22]. Isolated DNA, mainly derived from the apoptotic bodies occurred in cells, was subjected to $2.0 \%$ agarose electrophoresis at $50 \mathrm{~V}$ for $3 \mathrm{~h}$. DNA fragments, consisting of multimers of 160-200 base pairs, were visualized under ultraviolet light after staining with ethidium bromide.

2.7. Nuclear Staining. After treatment with MCME, cancer cells were fixed with $4 \%$ paraformaldehyde by $0.1 \%$ Triton X-100 and stained with $2 \mu \mathrm{g} / \mathrm{mL}$ of 4,6 -diamidine-2phenylindole (DAPI) for $30 \mathrm{~min}$ at room temperature. Cells were washed twice with PBS and morphologic changes of nuclei with apoptosis characteristic were determined and counted by fluorescence microscopy (IX71, Olympus Co.).

2.8. Western Blot. Cells were harvested after various treatments and lysed with lysis buffer, containing $1 \mathrm{mM}$ EDTA, $150 \mathrm{mM} \mathrm{NaCl}, 100 \mu \mathrm{g} / \mathrm{mL}$ PMSF, $50 \mathrm{mM}$ Tris- $\mathrm{HCl}$ (pH = 7.5), protease and phosphatase inhibitor cocktails (Sigma Co., MO, USA), and incubated on ice for $5 \mathrm{~min}$. After centrifugation for $15 \mathrm{~min}$ at $4^{\circ} \mathrm{C}$, the supernatant was transferred to fresh tube and stored at $-20^{\circ} \mathrm{C}$. Protein concentrations were determined using the Bradford protein assay reagent (Bio-Rad, CA, USA). For western blot analysis, equal amount of total protein was mixed with SDS sample buffer, incubated at $100^{\circ} \mathrm{C}$ for $5 \mathrm{~min}$ and separated by SDSpolyacrylamide gel electrophoresis. After electrophoresis, protein was blotted on a PVDF membrane (Millipore Co., Bedford, MA, USA) and blocked for $1 \mathrm{~h}$ in blocking solution at room temperature. Each membrane was incubated with appropriate primary antibodies at $4^{\circ} \mathrm{C}$ overnight and washed with PBST. The blots were incubated with the HRP-conjugated secondary antibodies at room temperature for $1 \mathrm{~h}$, washed three times with PBST, and then followed by visualization with Immobilon western (Millipore Co., Bedford, MA, USA).

2.9. Statistical Analysis. Quantified expression of proteins in all experiments was conducted using a densitometer (Personal Densitometer SI, Molecular Dynamics, Sunnyvale, CA, USA). All data were calculated as mean \pm SD. Statistical analysis of group differences was conducted using the one way ANOVA and the Tukey's post hoc test for multiple comparisons. A value of $P<0.05$ was considered statistically significant.

\section{Results}

3.1. Inhibition of Human Cancer Cell Growth by MCME. The effect of MCME on cell survival in four human cancer cell lines was evaluated for $24 \mathrm{~h}$ by an MTT assay. As shown in

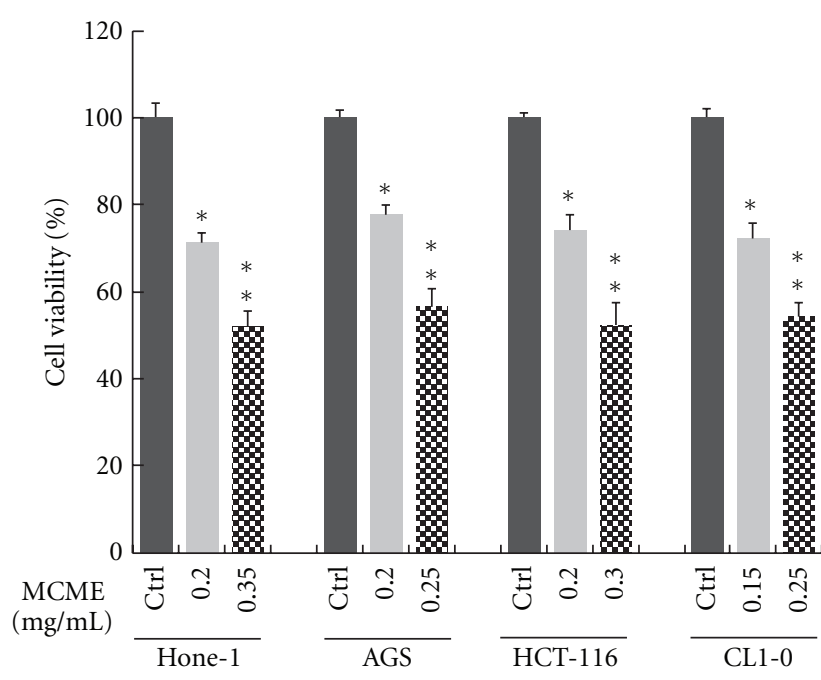

FIgure 1: Inhibitory effect of MCME on the viability of cancer cells. Hone-1, AGS, HCT-116, and CL1-0 cells were used to evaluate the anticancer activity of MCME. Cell viability was determined by dose-response curves obtained by the MTT assay. To comparatively evaluate the susceptibility of cells to MCME, data of each cell line were shown only at concentrations ranging from 0.15 to $0.35 \mathrm{mg} / \mathrm{mL}$ for the approximate viability of $75 \%$ and $50 \%$ at $24 \mathrm{~h}$ for each. All experiments were performed in triplicate, and results are expressed as mean \pm SD at a sample number of 8 for each experiment. $\left(^{*}\right)$ and $\left({ }^{* *}\right)$ indicate significant $P$ values $<0.05$ and $<0.01$, respectively, as compared to control (Ctrl).

Figure 1, Hone-1, AGS, HCT-116, and CL1-0 were exposed to $0.15 \sim 0.35 \mathrm{mg} / \mathrm{mL}$ MCME for $24 \mathrm{~h}$. MCME exhibited cytotoxic activity in all cancer cell lines tested, displaying a minor difference of $\mathrm{IC}_{50}$. The inhibitory effects were similar in Hone-1 cells (estimated $\mathrm{IC}_{50}, 0.35 \mathrm{mg} / \mathrm{mL}$ ), AGS cells (estimated $\mathrm{IC}_{50}, 0.3 \mathrm{mg} / \mathrm{mL}$ ), HCT-116 cells (estimated IC S0, , $0.3 \mathrm{mg} / \mathrm{mL}$ ), and CL1-0 cells (estimated $\mathrm{IC}_{50}, 0.25 \mathrm{mg} / \mathrm{mL}$ ). Approximately $50 \%$ of cancer cells survived after exposure for $24 \mathrm{~h}$ in each cell line, as follows: $52.0 \pm 3.5 \%$ for Hone1 cells, $56.5 \pm 4.2 \%$ for AGS cells, $52.3 \pm 5.1 \%$ for HCT116 cells, and $54.2 \pm 3.2 \%$ for CL1- 0 cells. Therefore, the susceptibility of these cancer cells to MCME was considered to be similar.

3.2. Effects of MCME on Apoptosis Induction. The cytotoxic effects of MCME on these cancer cells were investigated by examining the cell cycle distribution using PI staining. The quantitative data indicated that exposure to MCME induced an increased amount of cells at sub-G1 phase, whereas a reduced amount of cells in $\mathrm{S}$ phase to total cells, in all cancer cell lines. After treatment with MCME for $24 \mathrm{~h}$, the sub-G1 population increased from $4.6 \%$ to $28.2 \%$ in Hone- 1 cells, from $2.1 \%$ to $44.5 \%$ in AGS cells, from $5.1 \%$ to $34.5 \%$ in HCT-116 cells, and from $10.5 \%$ to $44.2 \%$ in CL1-0 cells (Figure 2).

The increased sub-G1 population indicated a less amount of MCME-treated cancer cells entering cell cycle after MCME treatment. However, cell population at sub-G1 phase was much less than that determined by cell viability 


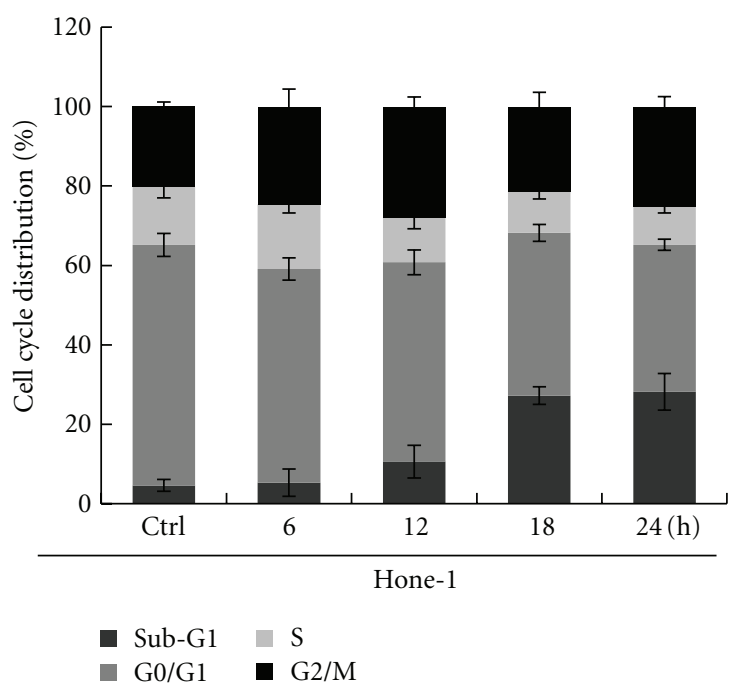

(a)

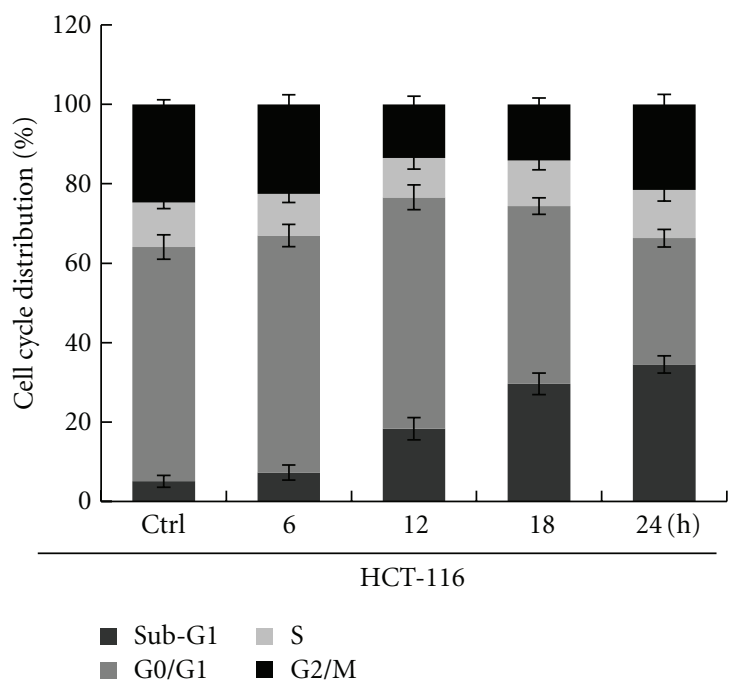

(c)

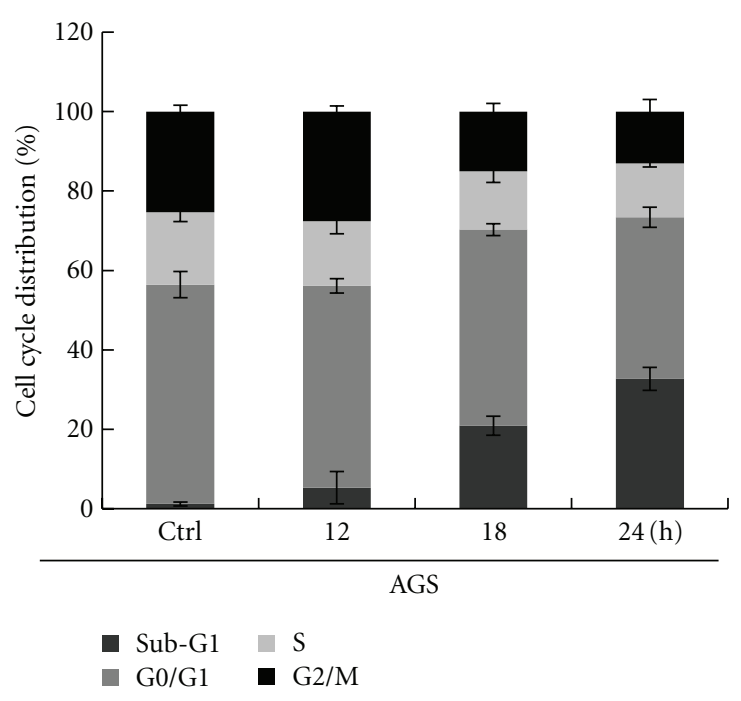

(b)

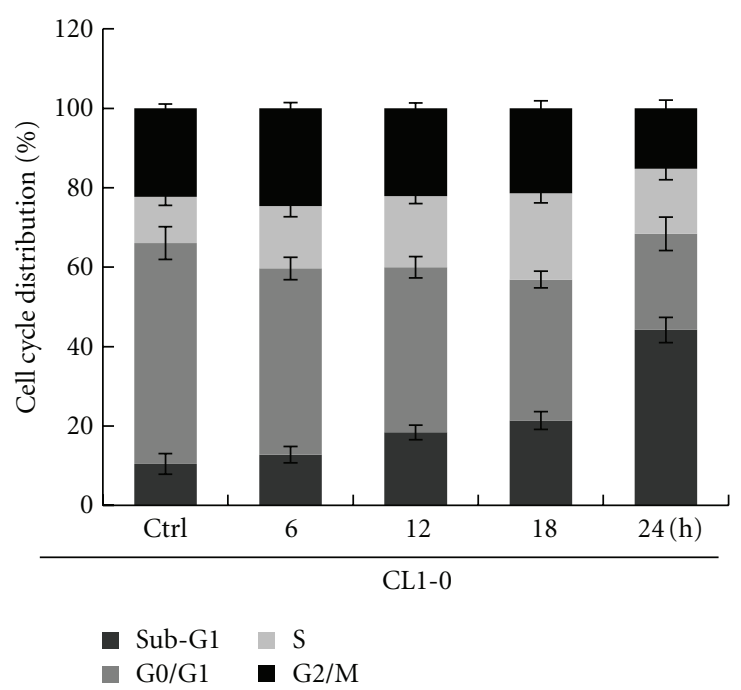

(d)

Figure 2: Cell cycle distribution of MCME-treated cancer cells. Cells were treated with MCME for 6, 12, 18, and 24 hours at a concentration of $0.35,0.25,0.3$, and $0.25 \mathrm{mg} / \mathrm{mL}$ for Hone-1, AGS, HCT-116, and CL1-0 cells, respectively. MCME-treated cells were analyzed by flow cytometry using PI staining to determine the population at sub-G1 phase. All experiments were performed in triplicate, and results were expressed as mean \pm SD. Ctrl indicates the control group of cells.

assay. To further evaluate MCME induced cell death in these cancer cells, DNA ladder pattern of internucleosomal DNA fragments was analyzed as shown in Figure 3. DNA fragmentation was observed in MCME-treated Hone-1, AGS, and HCT-116 cells from $12 \mathrm{~h}$ after treatment, whereas a significant ladder pattern of DNA fragmentation was found at $6 \mathrm{~h}$ in CL1-0 cells. These results indicated that MCME resulted in DNA fragmentation in cancer cells and the susceptibility of CL1-0 cells to MCME induced cell death was higher than that of Hone-1, AGS, and HCT-116 cells.

In addition, DNA damage was observed in all cell lines, as indicated by morphological changes in nuclei. It indicated that MCME caused marked apoptotic changes characterized by nuclear shrinkage and chromatin condensation (Figure 4(a)), which were quantified as shown in Figure 4(b). The increased percentage of apoptotic cells found after treatment with MCME for $24 \mathrm{~h}$, coincided with that evaluated by sub-G1 populations (Figure 2).

\subsection{MCME-Induced Apoptosis through Caspase-Dependent} Pathway. To explore the mechanism of MCME-induced apoptosis, activation of caspase and expression of proapoptogenic proteins were analyzed by western blotting. Caspase3 is one of the hallmarks of apoptosis and is responsible for inducing apoptosis by cleaving a variety of substrates such as 


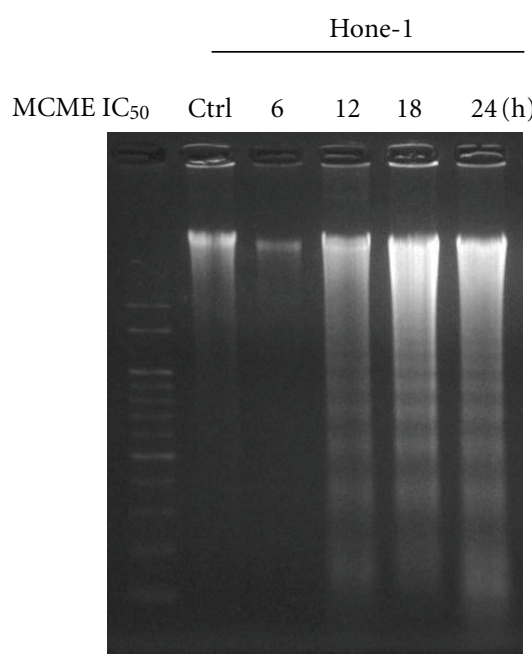

(a)

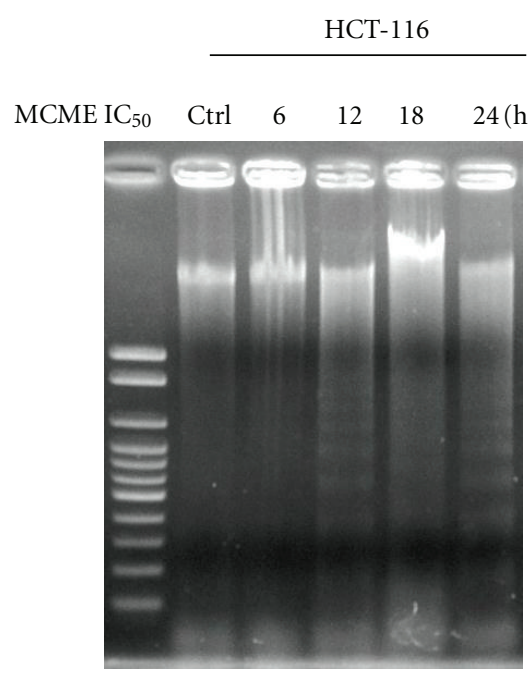

(c)

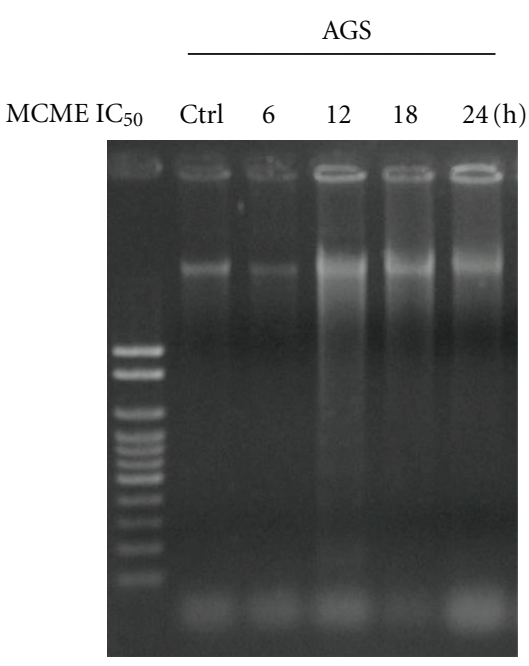

(b)

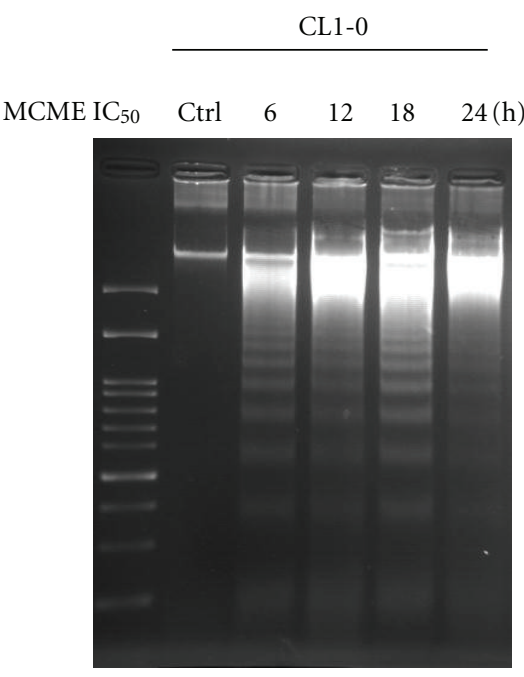

(d)

FIGURE 3: Induction of DNA fragmentation by MCME in cancer cells. Cells were treated at a number of $1 \times 10^{6}$ with MCME for 6, 12 , 18 , and 24 hours at a concentration of $0.35,0.25,0.3$, and $0.25 \mathrm{mg} / \mathrm{mL}$ for Hone-1, AGS, HCT-116, and CL1-0 cells, respectively. The DNA fragmentation of cells was detected on a $\%$ agarose gel electrophoresis. DNA fragmentation was visualized by Ethidium Bromide (EtBr) under UV light. Ctrl indicates the control group of cells.

DFF-45 (DNA fragmentation factor 45, also known as ICAD) and poly-(ADP-ribose) polymerase (PARP) [23, 24]. DFF-45 is the inhibitor of DFF-40 (also known as CAD), which is responsible for double-stranded DNA cleavage in apoptosis. The functional loss of DFF-45 allows DFF-40 to dimerize into the catalytic form, inducing DNA fragmentation [25]. To identify the mechanism involved in MCME-induced apoptosis, we investigated the activation of caspase- 3 and DFF-45 in cancer cells treated with MCME for $24 \mathrm{~h}$. MCME significantly decreased the activation of procaspase- 3 and the cleavage of DFF-45 (endogenous substrate of caspase-3) in a time-dependent manner $\left({ }^{*} P<0.05\right)$ (Figure 5$)$. These findings suggest that the activation of caspases involved in the apoptotic pathway is one of the major mechanisms by which MCME affects human cancer cell lines.

3.4. Effect of MCME on the Cleavage of PARP. PARP is a key signaling nuclear protein involved in triggering DNA repair [26]. This enzyme can catalyze poly (ADP-ribose) ligation to an acceptor protein, including itself. During apoptosis, PARP is cleaved by the activation of caspase-3, resulting in DNA damage and apoptosis [27]. As PARP is a downstream substrate of caspase-3, cleavage of PARP is an indicator of apoptosis. Treatment with MCME in all cancer cell lines resulted in the cleavage of PARP to yield an $85-\mathrm{kDa}$ cleaved fragment (Figure 5). After treatment with MCME for $24 \mathrm{~h}$, 

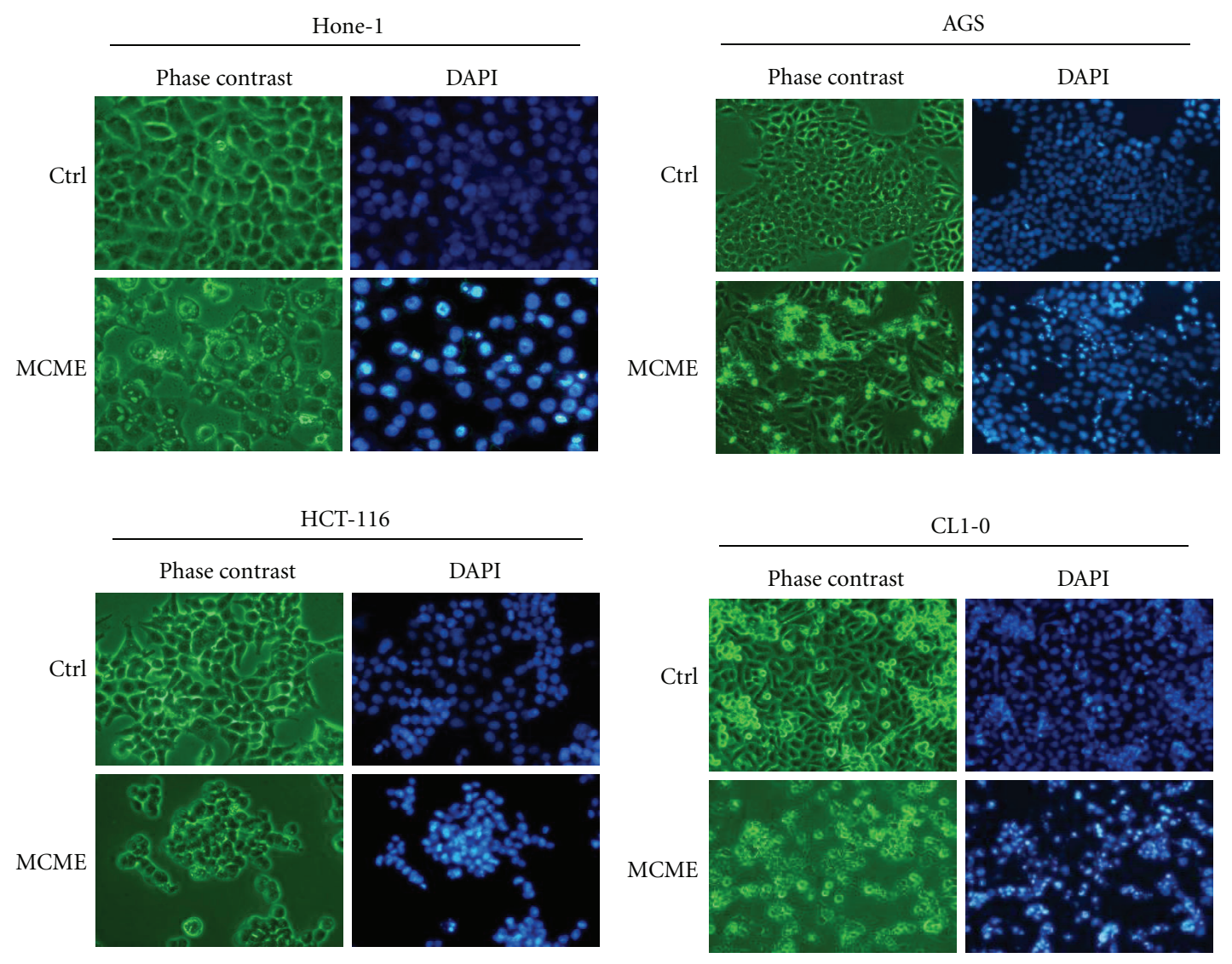

(a)

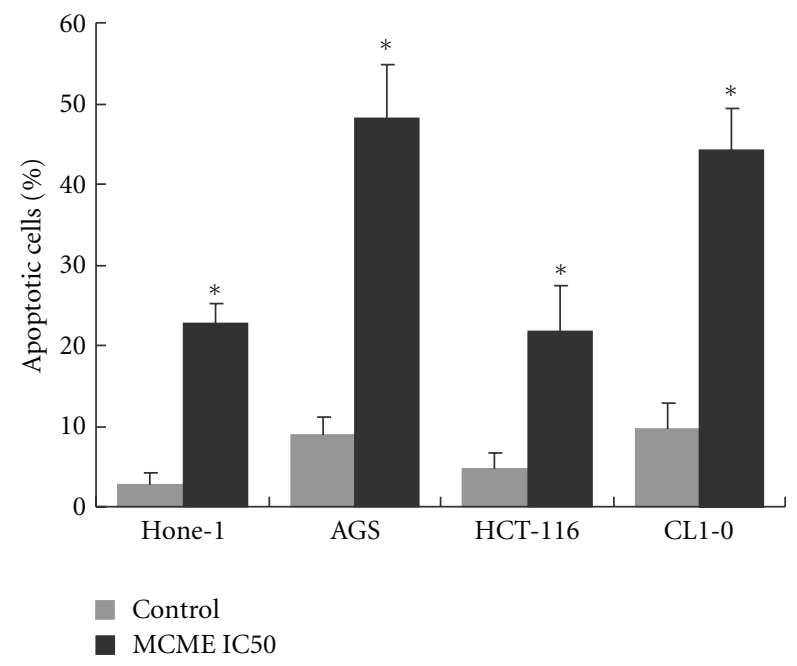

(b)

Figure 4: Analysis of the apoptosis in MCME-treated cancer cells. (a) Morphological changes of Hone-1, AGS, HCT-116, and CL1-0 cells treated with MCME at $0.35,0.25,0.3$, and $0.25 \mathrm{mg} / \mathrm{mL}$ for $24 \mathrm{~h}$. (b) Assessment of apoptotic cells in MCME-treated cancer cells. Cells with apoptotic characteristic DAPI-staining nuclei were counted by at least 1000 cells using fluorescence microscopy. Data were represented by mean \pm SD from three independent experiments. Asterisk $\left.{ }^{*}\right)$ indicates a significant $P$ value $<0.05$, as compared with controls. 

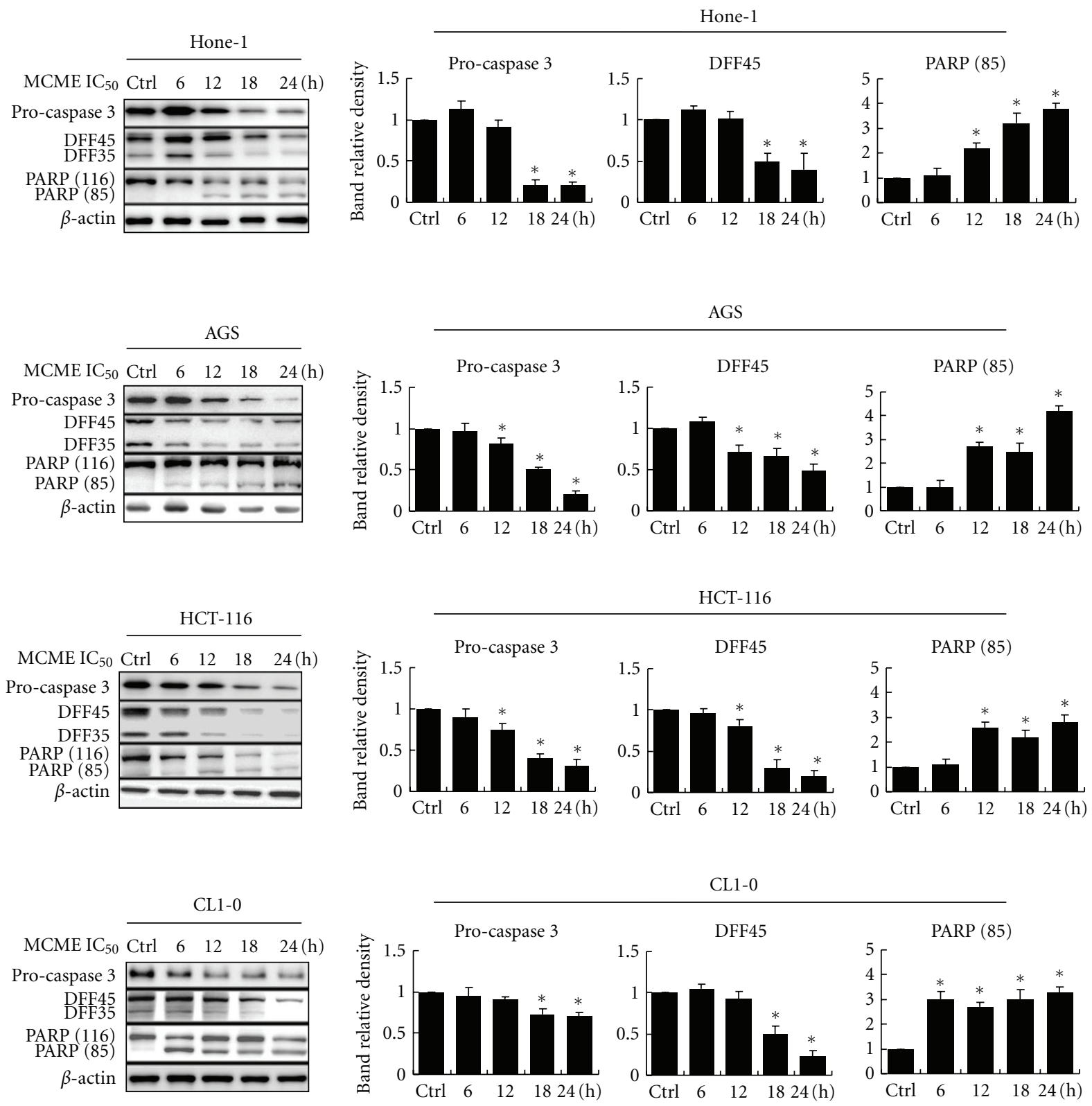

FIgURE 5: Expression of apoptogenic proteins in MCME-treated cancer cells. Hone-1, AGS, HCT-116, and CL1-0 cells were treated for 6, 12, 18 , and 24 hours with MCME at a concentration of $0.35,0.25,0.3$, and $0.25 \mathrm{mg} / \mathrm{mL}$, respectively. Equal amounts of lysates from these cancer cells treated with MCME were immunoblotted with anti-pro-caspase 3, anti-DFF, and anti-PARP antibodies. Blots were reproved with an antibody for $\beta$-actin to control for protein loading and transfer. Gels shown are representative of those obtained from three independent experiments. The protein expression levels were quantified and normalized to $\beta$-actin and expressed as the fold-change to the respective control. Asterisk $(*)$ indicates a significant $P$ value $<0.05$ as compared to controls.

PARP (85) showed a $3 \sim 5$-fold increase of activity at the approximate $\mathrm{IC}_{50}$ concentrations in all cancer cells $(* P<$ $0.05)$.

3.5. MCME-Mediated Expression of Bax and Bcl-2. Bcl-2 family proteins have a central role in controlling the mitochondrial pathway. The Bcl-2 family significantly regulates apoptosis either as an activator or as an inhibitor. It has been suggested that the $\mathrm{Bax} / \mathrm{Bcl}-2$ ratio was a key factor in regulation of the apoptotic process $[28,29]$. As shown in Figure 6, expression of proapoptotic Bax was significantly increased, whereas the antiapoptotic $\mathrm{Bcl}-2$ protein was decreased after treatment with MCME in a time-dependent manner. MCME-induced the increased expression of Bax and decreased expression of $\mathrm{Bcl}-2$, leading to a consequential increase of $\mathrm{Bax} / \mathrm{Bcl}-2$ ratio. $\mathrm{Bax} / \mathrm{Bcl}-2$ ratio was significantly increased by treating with MCME for $18 \mathrm{~h}$ and was increased with a range from 6.3 to 19.4 at $24 \mathrm{~h}$ on different cancer cells. The initiation of apoptosis through mitochondrial 

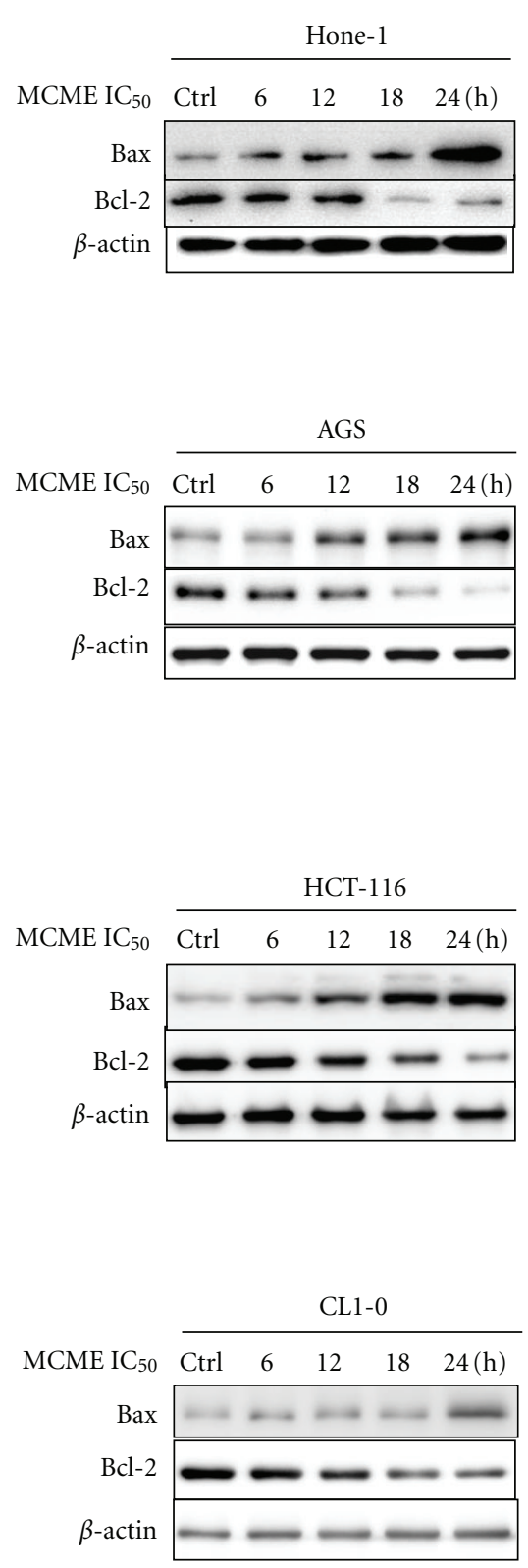

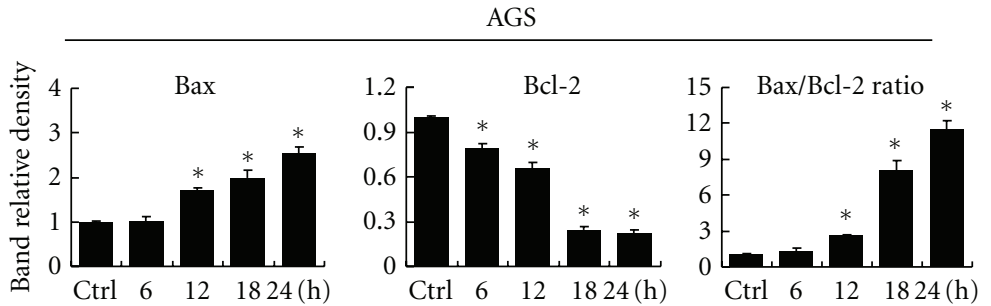

HCT-116
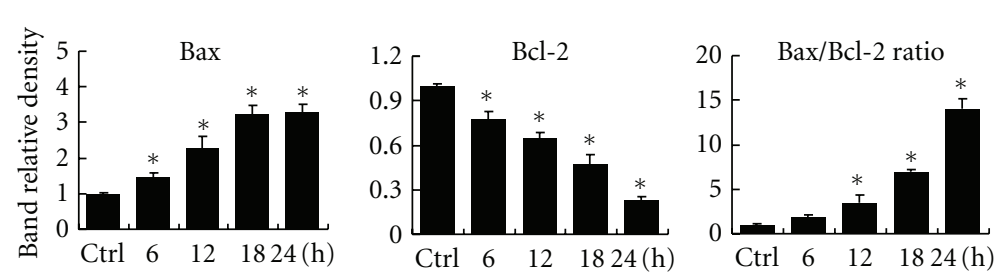

CL1-0
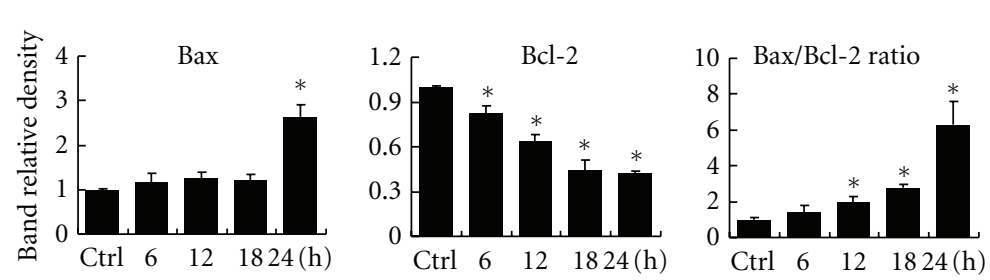

Figure 6: Expression of Bcl-2 family proteins in MCME-treated cancer cells. Hone-1, AGS, HCT-116, and CL1-0 cells were treated for 6, 12, 18 , and 24 hours with MCME at a concentration of $0.35,0.25,0.3$, and $0.25 \mathrm{mg} / \mathrm{mL}$, respectively. Equal amounts of lysates from these cancer cells treated with MCME were immunoblotted with anti-Bax and anti-Bcl-2 antibodies. Blots were reproved with an antibody for $\beta$-actin to control for protein loading and transfer. Gels shown are representative of those obtained from three independent experiments. The protein expression levels were quantified and normalized to $\beta$-actin and expressed as the fold-change to the respective control. Asterisk $(*)$ indicates a significant $P$ value $<0.05$ as compared to controls.

membrane permeability by the increased $\mathrm{Bax} / \mathrm{Bcl}-2$ ratio indicates that apoptosis induced by MCME is mitochondria related.

\section{Discussion}

Plant-derived herbal medicines have been used for a long time in several Asian countries. Anticancer activity is one among all the effects been reported by studies in vitro using natural herb extracts $[30,31]$. M. charantia, also called bitter melon, is a popular vegetable in Asia. The ability of this plant to decrease blood sugar was recognized more than 600 years ago [32]. Recent research confirms the presence of proteins and metabolites in $M$. charantia that exhibit hypoglycemic effect and act as antitumor and antiviral agents $[9,33,34]$. For instance, Kuguacin J and momorcharins 
were effective against human prostate cancer $[35,36]$. These findings suggest that $M$. charantia has great potential as a health food or a source for new drug development. In the current study, we extended the antitumor potential of $M$. charantia to other different cancers. Same as studies reported previously, MCME exhibited cytotoxicity on Hone-1, AGS, HCT-116, and CL1-0 cells, which was attributed to its action on the induction of cell death.

Apoptosis is a programmed cell death that can occur by a variety of internal or external stimuli, and these signals are controlled by two distinct pathways. One is an extrinsic pathway (death receptor pathway), and the other is an intrinsic pathway in which mitochondria are involved [37, $38]$. Caspases play a key role in apoptosis $[39,40]$. A regulatory cascade eventually leads to the activation of effector caspases, such as caspase-3. These caspases are responsible for the cleavage of cellular proteins, such as cytoskeletal components, leading to the typical morphological changes observed in cells undergoing apoptosis [41]. Our results indicated that MCME increased caspase-3 activity in Hone1, AGS, HCT-116, and CL1-0 cells in a time-dependent manner. Programmed cell death involves the activation of caspases and the subsequent cleavage of several substrates such as actin, PARP, gelsolin, DFF-45, lamins, and fodrin [42]. PARP is involved in repairing DNA damage by catalyzing the synthesis of poly (ADP-ribose), binding to DNA strand breaks, and modifying nuclear proteins [23, 24, 43]. The ability of PARP to repair DNA damage is prevented by cleavage of PARP by caspase-3 [44]. The fragmentation of DNA into nucleosomal units as seen in DNA fragmentation assays is caused by an enzyme known as DFF-40, or caspaseactivated DNase. Normally, DFF-40 exists as an inactive complex with its inhibitor, DFF-45. During apoptosis, DFF45 is cleaved by caspases, such as caspase- 3 , to release DFF40 and followed by rapid fragmentation of the nuclear DNA $[45,46]$.

In this study, we found that MCME exhibited a significant effect on the morphological and biochemical features of the cancer cells tested, indicating that MCME induces apoptosis in both dose- and time-dependent manner. We observed that treatment of cells with up to $0.15 \sim 0.2 \mathrm{mg} / \mathrm{mL}$ MCME reduced one fourth of cell viability, whereas about a half of cell viability was found at $0.25 \sim 0.35 \mathrm{mg} / \mathrm{mL}$. MCME significantly inhibited cell viability and induced chromatin condensation in Hone-1, AGS, HCT-116, and CL1-0 cells. In addition, MCME induced the cleavage of caspase- 3 and DFF-45, and the activation of PARP, leading to DNA fragmentation. Among all the tested cancer cells, CL1-0 cells were more susceptible to MCME with a lower $\mathrm{IC}_{50}$ and the apace increased cleavage of PARP and DNA fragmentation at $6 \mathrm{~h}$ after treatment. Cells containing apoptotic bodies confirmed that MCME-induced cell death and sub-G1 populations in CL1-0 and AGS cells were mainly mediated through caspase-dependent apoptotic pathway. However, the lower population of cells with apoptotic bodies and subG1 phase distribution imply some other pathways may be involved in MCME-reduced viability in Hone-1 and HCT116 cells.
Both biochemical and genetic evidence indicates that Bcl-2 family members, including proapoptotic proteins such as Bax, Bak and antiapoptotic proteins such as Bcl-2, Bcl$\mathrm{xl}$, can regulate cell death induced by caspases $[47,48]$. In recent years, the importance of $\mathrm{Bcl}-2$ family members in mitochondria-associated apoptotic network is noticed [49]. $\mathrm{Bcl}-2$, a caspase substrate, can function as an antioxidant to inhibit apoptosis in a wide variety of cell types, which play a vital role in regulating the mitochondria-dependent pathway [50]. The Bax/Bcl-2 ratio can be recognized as a key factor for apoptotic process by regulating cytochrome $c$ from mitochondria to cytosol [51,52]. Extract of $M$. charantia was reported to inhibit growth of several cancer cells by augmenting Bax/Bcl-2, Bad/Bcl-2, or Bak/Bcl-2 [36, 53]. Our results showed that $\mathrm{Bcl}-2$ was significantly decreased and $\mathrm{Bax}$ was increased in MCME-treated cancer cells. The increased $\mathrm{Bax} / \mathrm{Bcl}-2$ ratio indicates that mitochondria-mediated apoptosis is involved in MCME-induced cell death in these treated cell lines [49]. The activation of caspase- 3 and enhanced production of cleaved PARP, subsequently leading to DNA fragmentation and apoptosis, in MCME-treated cancer cells coincided with that treated by Kuguacin J, a triterpenoid, and Rutin, a flavonoid, from leaf of M. charantia, in leukemia, prostate, and ovarian cancer cells $[36,54,55]$. Therefore, both Kuguacin J and Rutin may be the active components exhibiting anti-cancer activity in MCME. Interestingly, our results on Hone-1 nasopharyngeal carcinoma cells did not meet the unchanged Bcl-2 expression in M. charantia lectininduced apoptosis in another nasopharyngeal carcinoma CNE-1 cells [19]. It indicates that MCME mediated different processes in cancer cells toward apoptosis.

Owing to the edible properties of M. charantia, two cancer cell lines of digestive track, AGS and HCT-116 cells, were used to comparatively investigate the anticancer effect of $M$. charantia on two other cancer cell lines, Hone- 1 and CL1-0 cells, in this study. In spite to the difference of MCMEinduced cell viability, all these cells represent a susceptibility to MCME-induced cell death through caspase- and mitochondria-dependent apoptotic pathways. Since people consume fruit and/or leaves of M. charantia as food in Asia, MCME used in this study represents a promising candidate agent to develop for cancer prevention in the future.

\section{Conclusion}

In conclusion, we demonstrated that caspase- and mitochondria-dependent pathways are involved in MCMEinduced apoptosis in Hone-1, AGS, HCT-116, and CL1-0 cancer cells. Since a lot of processes may be initiated, cell death other than apoptosis is probably involved in death stimuli in these cancer cells by MCME. Edible materials possess anti-cancer properties, may be particularly useful for synergistic remedy with conventional drugs to circumvent drug resistance in cancer therapy. MCME that can initiate anti-cancer actions through caspase- and mitochondria-dependent pathways exhibits the potential for complementary therapy on cancers. 


\section{Acknowledgments}

The authors thank Dr. Jih-I Yeh for his assistance in statistical analysis and Chia-Lin Ho and Jung-Hsuan Lin for their help in cell preparation or eletrophoresis. This work was supported by Grant 96AS-1.2.1-ST-a1 from the Council of Agriculture and Grants 61040055-10 and TCIRP96005-01 from Tzu-Chi University, Taiwan.

\section{References}

[1] I. T. Johnson, "New approaches to the role of diet in the prevention of cancers of the alimentary tract," Mutation Research, vol. 551, no. 1-2, pp. 9-28, 2004.

[2] M. P. Kähkönen, A. I. Hopia, H. J. Vuorela et al., "Antioxidant activity of plant extracts containing phenolic compounds," Journal of Agricultural and Food Chemistry, vol. 47, no. 10, pp. 3954-3962, 1999.

[3] W. S. Jeong, M. Jun, and A. N. Kong, "Nrf2: a potential molecular target for cancer chemoprevention by natural compounds," Antioxidants \& Redox Signaling, vol. 8, no. 1-2, pp. 99-106, 2006.

[4] C. Manach, A. Scalbert, C. Morand, C. Remesy, and L. Jimenez, "Polyphenols: food sources and bioavailability," The American Journal of Clinical Nutrition, vol. 79, no. 5, pp. 727747, 2004.

[5] E. Riboli and T. Norat, "Epidemiologic evidence of the protective effect of fruit and vegetables on cancer risk," The American Journal of Clinical Nutrition, vol. 78, no. 3, pp. 559S569S, 2003.

[6] M. H. Carlsen, B. L. Halvorsen, K. Holte et al., "The total antioxidant content of more than 3100 foods, beverages, spices, herbs and supplements used worldwide," Nutrition Journal, vol. 9, no. 1, article 3, 2010.

[7] J. K. Grover and S. P. Yadav, "Pharmacological actions and potential uses of Momordica charantia: a review," Journal of Ethnopharmacology, vol. 93, no. 1, pp. 123-132, 2004.

[8] T. B. Ng, "Biological and immunological activities of bovine placental gonadotropin," International Journal of Biochemistry and Molecular Biology, vol. 31, no. 6, pp. 1149-1156, 1993.

[9] F. Stirpe, "Ribosome-inactivating proteins," Toxicon, vol. 44, pp. 371-383, 2004.

[10] M. Li, Y. Chen, Z. Liu, F. Shen, X. Bian, and Y. Meng, "Antitumor activity and immunological modification of ribosomeinactivating protein (RIP) from Momordica charantia by covalent attachment of polyethylene glycol," Acta Biochimica et Biophysica Sinica, vol. 41, no. 9, pp. 792-799, 2009.

[11] G. V. Senanayake, N. Fukuda, S. Nshizono et al., "Mechanisms underlying decreased hepatic triacylglycerol and cholesterol by dietary bitter melon extract in the rat," Lipids, vol. 47, pp. 495503, 2012.

[12] P. C. Liao, C. C. Tsai, C. H. Chou, and Y. C. Chiang, "Introgression between cultivars and wild populations of Momordica charantia L., (Cucurbitaceae) in Taiwan," International Journal of Molecular Sciences, vol. 13, no. 5, pp. 6469-6491, 2012.

[13] R. B. Ray, A. Raychoudhuri, R. Steele, and P. Nerurkar, "Bitter Melon (Momordica charantia) extract inhibits breast cancer cell proliferation by modulating cell cycle regulatory genes and promotes apoptosis," Cancer Research, vol. 70, no. 5, pp. 19251931, 2010.

[14] H. Wang and T. B. Ng, "Ribosome inactivating protein and lectin from bitter melon (Momordica charantia) seeds: sequence comparison with related proteins," Biochemical and
Biophysical Research Communications, vol. 253, no. 1, pp. 143146, 1998.

[15] Y. H. Hwang, W. L. Jung, E. R. Hahm et al., "Momordin I, an inhibitor of AP-1, suppressed osteoclastogenesis through inhibition of NF- $\kappa \mathrm{B}$ and $\mathrm{AP}-1$ and also reduced osteoclast activity and survival," Biochemical and Biophysical Research Communications, vol. 337, no. 3, pp. 815-823, 2005.

[16] S. Lee-Huang, P. L. Huang, P. L. Nara et al., "MAP 30: a new inhibitor of HIV-1 infection and replication," FEBS Letters, vol. 272, pp. 12-18, 1990.

[17] S. Lee-Huang, P. L. Huang, H. C. Chen et al., "Anti-HIV and anti-tumor activities of recombinant MAP30 from bitter melon," Gene, vol. 161, no. 2, pp. 151-156, 1995.

[18] E. F. Fang, C. Z. Zhang, W. P. Fong, and T. B. Ng, "RNase MC2: a new Momordica charantia ribonuclease that induces apoptosis in breast cancer cells associated with activation of MAPKs and induction of caspase pathways," Apoptosis, vol. 17, pp. 377-387, 2012.

[19] E. F. Fang, C. Z. Zhang, T. B. Ng et al., "Momordica Charantia lectin, a type II ribosome inactivating protein, exhibits antitumor activity toward human nasopharyngeal carcinoma cells in vitro and in vivo," Cancer Prevention Research, vol. 5, no. 5, pp. 109-121, 2012.

[20] X. Wang, W. Sun, J. Cao, H. Qu, X. Bi, and Y. Zhao, "Structures of new triterpenoids and cytotoxicity activities of the isolated major compounds from the fruit of Momordica charantia L," Journal of Agricultural and Food Chemistry, vol. 60, pp. 39273933, 2012.

[21] I. Inkielewicz-Stepniak, M. W. Radomski, and M. Wozniak, "Fisetin prevents fluoride- and dexamethasone-induced oxidative damage in osteoblast and hippocampal cells," Food and Chemical Toxicology, vol. 50, pp. 583-589, 2011.

[22] M. Herrmann, H. M. Lorenz, R. Voll, M. Grunke, W. Woith, and J. R. Kalden, "A rapid and simple method for the isolation of apoptotic DNA fragments," Nucleic Acids Research, vol. 22, no. 24, pp. 5506-5507, 1994.

[23] A. Rosen and L. Casciola-Rosen, "Macromolecular substrates for the ICE-like proteases during apoptosis," Journal of Cellular Biochemistry, vol. 64, Article ID 901575, pp. 50-54, 1997.

[24] B. Shu, W. Duan, J. Yao, J. Huang, Z. Jiang, and L. Zhang, "Caspase 3 is involved in the apoptosis induced by triptolide in HK-2 cells," Toxicol In Vitro, vol. 23, pp. 598-602, 2009.

[25] T. Otomo, H. Sakahira, K. Uegaki, S. Nagata, and T. Yamazaki, "Structure of the heterodimeric complex between CAD domains of CAD and ICAD," Nature Structural \& Molecular Biology, vol. 7, pp. 658-662, 2000.

[26] L. Geng, A. M. Huehls, J. M. Wagner, C. J. Huntoon, and L. M. Karnitz, "Checkpoint signalingbase excision repair, and PARP promote survival of colon cancer cells treated with 5fluorodeoxyuridine but not 5-fluorouracil," PLoS ONE, vol. 6, Article ID e28862, 2011.

[27] S. H. Kaufmann, S. Desnoyers, Y. Ottaviano, N. E. Davidson, and G. G. Poirier, "Specific proteolytic cleavage of poly(ADPribose) polymerase: an early marker of chemotherapy-induced apoptosis," Cancer Research, vol. 53, pp. 3976-3985, 1993.

[28] S. Thees, G. B. Hubbard, J. Winckler, C. Schultz, and A. Rami, "Specific alteration of the $\mathrm{Bax} / \mathrm{Bcl} 2$ ratio and cytochrome $\mathrm{c}$ without execution of apoptosis in the hippocampus of aged baboons," Restorative Neurology and Neuroscience, vol. 23, no. 1, pp. 1-9, 2005.

[29] S. Zinkel, A. Gross, and E. Yang, "BCL2 family in DNA damage and cell cycle control," Cell Death and Differentiation, vol. 13, no. 8, pp. 1351-1359, 2006. 
[30] C. Kandaswami, L. T. Lee, P. P. Lee et al., "The antitumor activities of flavonoids," In Vivo, vol. 19, pp. 895-909, 2005.

[31] C. W. Cheng, W. Fan, S. G. Ko, L. Song, and Z. X. Bian, "Evidence-based management of herb-drug interaction in cancer chemotherapy," Explore, vol. 6, pp. 324-329, 2010.

[32] L. Leung, R. Birtwhistle, J. Kotecha, S. Hannah, and S. Cuthbertson, "Anti-diabetic and hypoglycaemic effects of Momordica charantia (bitter melon): a mini review," British Journal of Nutrition, vol. 102, no. 12, pp. 1703-1708, 2009.

[33] A. S. Bourinbaiar and S. Lee-Huang, "The activity of plantderived antiretroviral proteins MAP30 and GAP31 against herpes simplex virus in vitro," Biochemical and Biophysical Research Communications, vol. 219, pp. 923-929, 1996.

[34] E. F. Fang and T. B. Ng, "Bitter gourd (Momordica charantia) is a cornucopia of health: a review of its credited antidiabetic, Anti-HIV, and antitumor properties," Current Molecular Medicine, vol. 11, no. 5, pp. 417-436, 2011.

[35] S. D. Xiong, K. Yu, X. H. Liu et al., "Ribosome-inactivating proteins isolated from dietary bitter melon induce apoptosis and inhibit histone deacetylase- 1 selectively in premalignant and malignant prostate cancer cells," International Journal of Cancer, vol. 125, no. 4, pp. 774-782, 2009.

[36] P. Pitchakarn, S. Suzuki, K. Ogawa et al., "Induction of G1 arrest and apoptosis in androgen-dependent human prostate cancer by Kuguacin J, a triterpenoid from Momordica charantia leaf," Cancer Letters, vol. 306, no. 2, pp. 142-150, 2011.

[37] I. Chowdhury, B. Tharakan, and G. K. Bhat, "Current concepts in apoptosis: the physiological suicide program revisited," Cellular and Molecular Biology Letters, vol. 11, pp. 506-525, 2006.

[38] C. Burz, I. Berindan-Neagoe, O. Balacescu, and A. Irimie, "Apoptosis in cancer: key molecular signaling pathways and therapy targets," Acta Oncologica, vol. 48, no. 6, pp. 811-821, 2009.

[39] T. J. Fan, L. H. Han, R. S. Cong, and J. Liang, "Caspase family proteases and apoptosis," Acta Biochimica et Biophysica Sinica, vol. 37, pp. 719-727, 2005.

[40] I. Kitazumi and M. Tsukahara, "Regulation of DNA fragmentation: the role of caspases and phosphorylation," FEBS Journal, vol. 278, pp. 427-441, 2011.

[41] S. Kothakota, T. Azuma, C. Reinhard et al., "Caspase-3generated fragment of gelsolin: effector of morphological change in apoptosis," Science, vol. 278, no. 5336, pp. 294-298, 1997.

[42] E. A. Slee, C. Adrain, and S. J. Martin, "Executioner caspase$3,-6$, and -7 perform distinct, non-redundant roles during the demolition phase of apoptosis," Journal of Biological Chemistry, vol. 276, no. 10, pp. 7320-7326, 2001.

[43] P. Decker and S. Muller, "Modulating poly, (ADP-ribose) polymerase activity: potential for the prevention and therapy of pathogenic situations involving DNA damage and oxidative stress," Current Pharmaceutical Biotechnology, vol. 3, pp. 275283, 2002.

[44] C. Soldani and A. I. Scovassi, "Poly(ADP-ribose) polymerase1 cleavage during apoptosis: an update," Apoptosis, vol. 7, no. 4, pp. 321-328, 2002.

[45] B. Zhivotovsky, D. H. Burgess, D. M. Vanags, and S. Orrenius, "Involvement of cellular proteolytic machinery in apoptosis," Biochemical and Biophysical Research Communications, vol. 230, no. 3, pp. 481-488, 1997.
[46] Y. A. Lazebnik, S. H. Kaufmann, S. Desnoyers, G. G. Poirier, and W. C. Earnshaw, "Cleavage of poly(ADP-ribose) polymerase by a proteinase with properties like ICE," Nature, vol. 371, no. 6495, pp. 346-347, 1994.

[47] A. M. Chinnaiyan, K. O’Rourke, B. R. Lane, and V. M. Dixit, "Interaction of CED-4 with CED-3 and CED-9: a molecular framework for cell death," Science, vol. 275, no. 5303, pp. 1122-1126, 1997.

[48] M. S. Ola, M. Nawaz, and H. Ahsan, "Role of Bcl-2 family proteins and caspases in the regulation of apoptosis," Molecular and Cellular Biochemistry, vol. 351, pp. 41-58, 2011.

[49] J. C. Martinou and R. J. Youle, "Mitochondria in apoptosis: Bcl-2 family members and mitochondrial dynamics," Developmental Cell, vol. 21, pp. 92-101, 2011.

[50] E. H. Y. Cheng, D. G. Kirsch, R. J. Clem et al., "Conversion of Bcl-2 to a bax-like death effector by caspases," Science, vol. 278, no. 5345, pp. 1966-1968, 1997.

[51] H. L. Yang, C. S. Chen, W. H. Chang et al., "Growth inhibition and induction of apoptosis in MCF-7 breast cancer cells by Antrodia camphorata," Cancer Letters, vol. 231, no. 2, pp. 215227, 2006.

[52] S. M. Kilbride and J. H. Prehn, "Central roles of apoptotic proteins inmitochondrial function," Oncogene. In press.

[53] E. F. Fang, C. Z. Zhang, L. Zhang, W. P. Fong, and T. B. Ng, "In vitro and in vivo anticarcinogenic effects of RNase MC2, a ribonuclease isolated from dietary bitter gourd, toward human liver cancer cells," The International Journal of Biochemistry \& Cell Biology, vol. 44, pp. 1351-1360, 2012.

[54] J. P. Lin, J. S. Yang, C. C. Lu et al., "Rutin inhibits the proliferation of murine leukemia WEHI-3 cells in vivo and promotes immune response in vivo," Leukemia Research, vol. 33, no. 6, pp. 823-828, 2009.

[55] H. Luo, B. H. Jiang, S. M. King, and Y. C. Chen, "Inhibition of cell growth and VEGF expression in ovarian cancer cells by flavonoids," Nutrition and Cancer, vol. 60, pp. 800-809, 2008. 


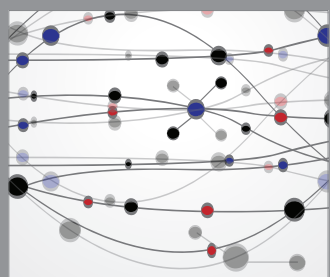

The Scientific World Journal
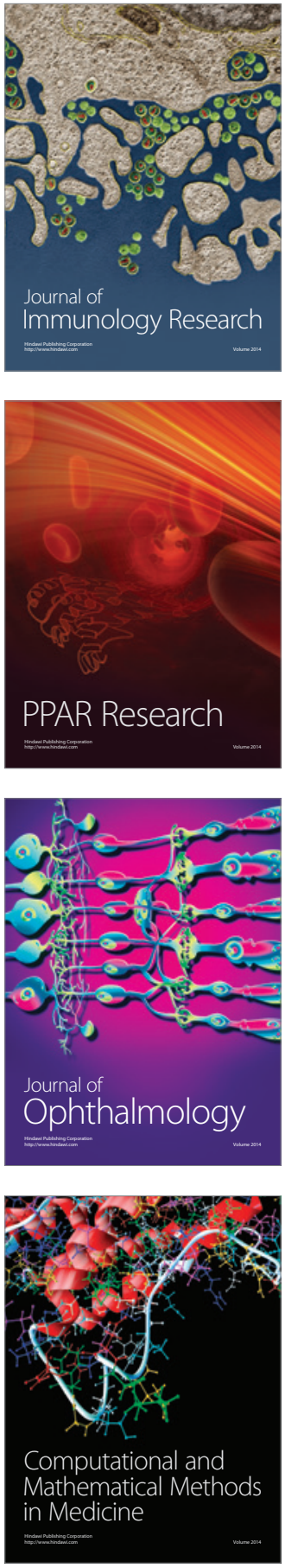

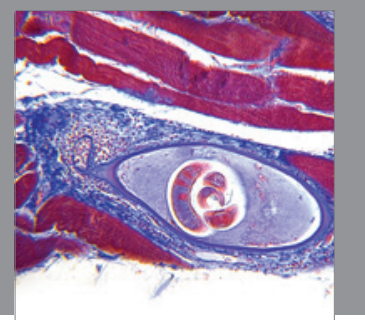

Gastroenterology

Research and Practice
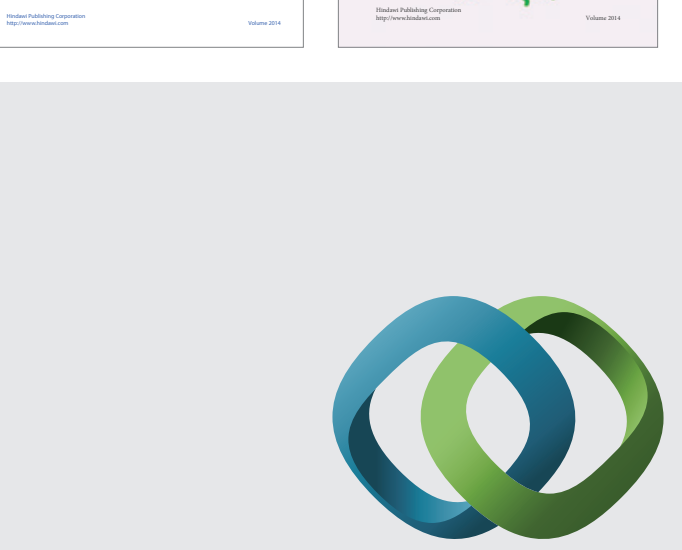

\section{Hindawi}

Submit your manuscripts at

http://www.hindawi.com
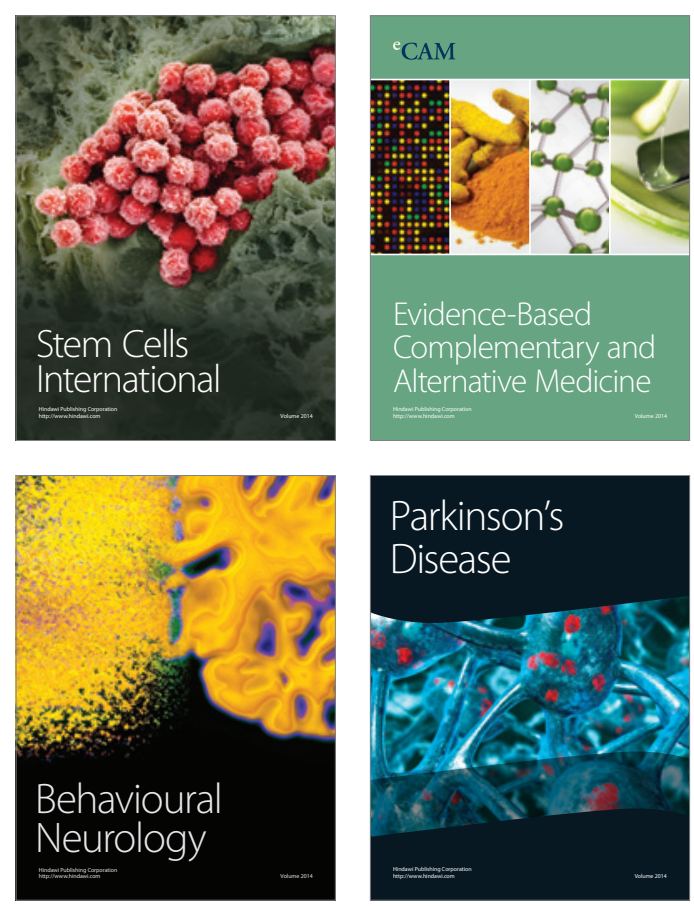

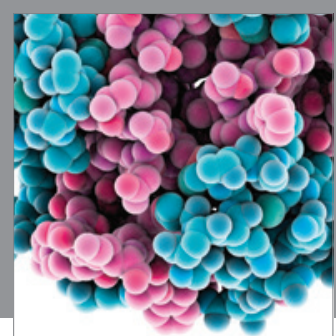

Journal of
Diabetes Research

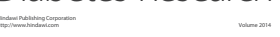

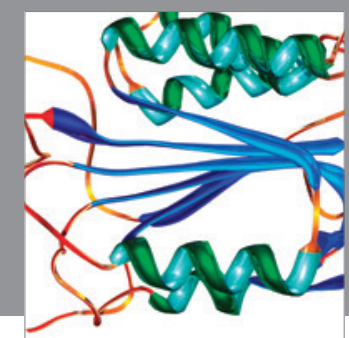

Disease Markers
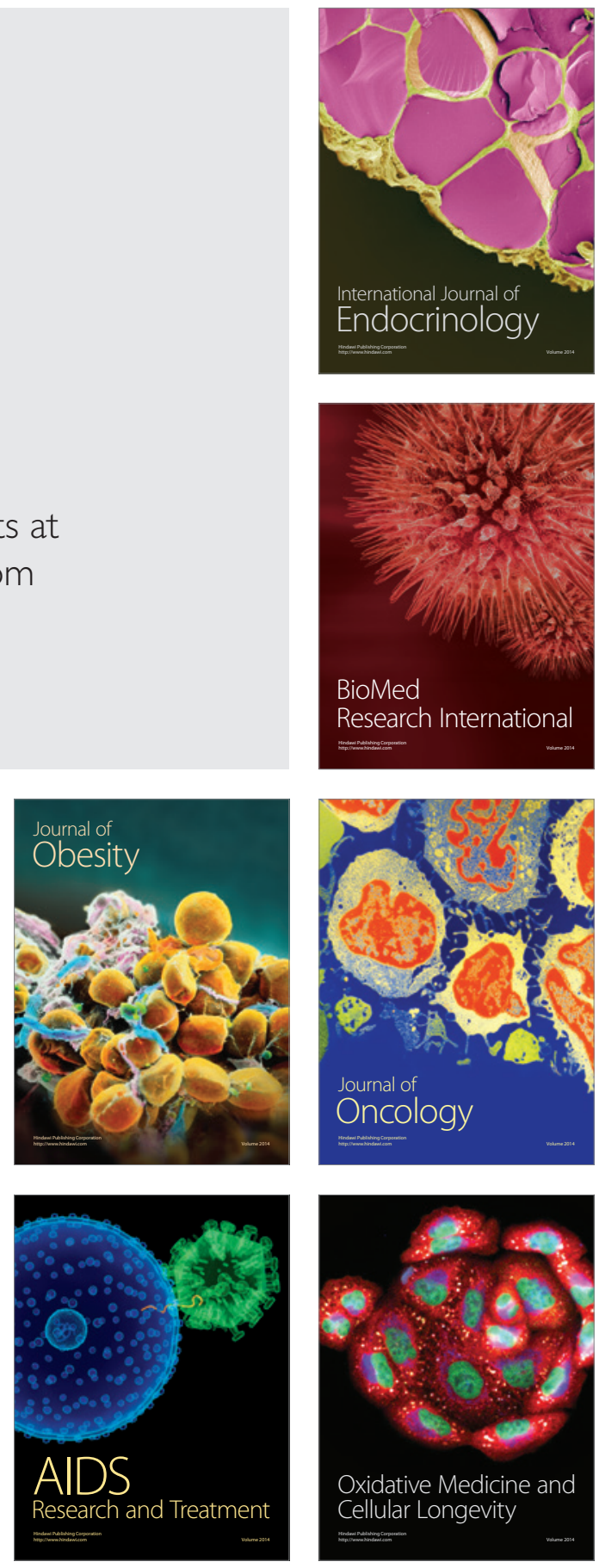